Article

\title{
Teaching Incest Narratives, Student Survivors, and Inclusive Pedagogy
}

\author{
Andrea Nicki \\ Independent scholar, Farleigh Dickinson University, Teaneck, NJ 07666, USA; anicki@fdu.edu
}

Received: 29 March 2018; Accepted: 8 May 2018; Published: 11 May 2018

\begin{abstract}
I examine and challenge the view, expressed by some literary theorists, that writings about trauma should be read and taught differently from other writings because these reflect a desire to heal with the support of a community of readers. I explore some poems about incest, including my own, and the expressed intentions and intellectual processes of the authors. I argue that framing these writings as healing narratives misconceives the writers as healers. I address some challenges in teaching incest narratives and strategies that can help ensure the inclusion of student incest survivors and, generally, student survivors of chronic childhood trauma. While some scholars have emphasized the importance of instructors providing trigger warnings when assigning material about trauma, students of chronic childhood trauma can be triggered by wide-ranging material. I emphasize that these students need to be recognized as a minority group facing disadvantages and discrimination, and discuss how educational institutes and campus services could be improved to better meet their needs. Further, I elaborate how survivor-inclusive pedagogy gives a central place in diverse curricula to first-person narratives and experiences of survivors. Finally, I note some encouraging developments in the fields of psychology and law and make some recommendations.
\end{abstract}

Keywords: incest narratives; survivors of chronic childhood trauma; trigger warnings; inclusive pedagogy; psychological disability

\section{Introduction}

Some literary theorists have assumed that nonfiction and creative writing that explores trauma should not be read or taught in the same way as other nonfiction and creative writing (Rak 2003; Spear 2014). This assumption stems from the belief that writings about trauma, referred to as "trauma narratives," are different in kind, and reflect a desire to heal with the support of a community of readers (Rak 2003; Spear 2014). I explore some poems about incest by women, including my own poems, and the expressed intentions and writing processes of the authors. I emphasize that while writing about trauma can have some healing value for the authors, they are first and foremost writers and not healers.

I claim that framing writings that explore trauma as "trauma narratives," and as having primarily therapeutic value for the authors, medicalizes and marginalizes them. This treatment is reminiscent of responses that female incest survivors receive from mental health professionals and others. As I discuss in my article "Borderline Personality Disorder, Discrimination, and Survivors of Chronic Childhood Trauma" (Nicki 2016a), psychiatrists and other mental health professionals typically diagnose women who report chronic childhood abuse by a caretaker as having borderline personality disorder (BPD), and as having deficient, pathological personalities. Much of their behaviour is misunderstood and interpreted negatively and simplistically as manifesting pathology, and not strengths, or positive abilities and skills. Clinicians report feelings of hostility toward patients diagnosed with BPD and view them as manipulative and deliberately difficult (quoted in Nicki 2016a, p. 219). As I claim in my article, when female survivors reveal a history of chronic childhood trauma and share their family life 
experiences in social settings, they often experience a lack of warmth and exclusion, and a direction to seek the support of mental health professionals (Nicki 2016a, p. 223). They are othered and seen only in terms of the identity of wounded survivor, without other life experiences, interests, goals, or ambitions.

I argue that educators who teach writings about incest should, to avoid promoting the marginalization of incest survivors, use a pedagogical approach that emphasizes the importance of including and learning about diverse family life experiences and social justice issues. I explore some challenges in teaching incest narratives and the preliminary work that is needed to ensure a discussion that is respectful and inclusive of student incest survivors. Some scholars have emphasized the importance of instructors providing trigger warnings when assigning and material about traumatic experiences, such as sexual violence, domestic violence, and violence against children, and argue that such warnings can serve to make course material more accessible (Carter 2015; Price 2012). However, I argue that framing certain issues as inherently triggering presents these problems as primarily medical ones and de-contextualizes experiences of violence which include an aftermath of responses. For student survivors of incest and, generally, student survivors of chronic childhood trauma, there can be many, widely varying reminders of traumas and wounding experiences, including exclusionary behaviour from professors or classmates arising from uninformed views.

I argue that student survivors of chronic childhood trauma need to be recognized as a minority group facing disadvantages and discrimination in education. While they typically have psychological challenges, such as depression, anxiety, and flashbacks, which can impede their academic performance, providing accommodations for these challenges is not enough to level the playing field for them. I discuss how educational institutes and campus services could be improved to better meet their needs and mention some current initiatives that recognize them as experts on their lived experience. Further, I elaborate on survivor-inclusive pedagogy which gives a central place in diverse curricula to first-person narratives and experiences of survivors. Finally, I note some encouraging developments in the fields of psychology and law and make some recommendations.

\section{Incest Narratives and Authors' Statements}

In "Do Witness: Don't: A Woman's Word and Trauma as Pedagogy" (2003), Julie Rak draws on the work of trauma theorists like Laub (1992) and Caruth (1995) and argues that trauma narratives are fundamentally different from other narratives in that they arise from the author's desire to be healed. She focuses on Elly Danica's book Don't: A Woman's Word (Danica 1988, an autobiographical book of prose poems about chronic childhood abuse and incest. She argues that narratives like Don't "seek to enact secondary trauma within readers," who bear witness to the trauma and, as result, produce healing in the authors (Rak 2003, p. 53): “Unlike other types of narrative, narrative about trauma requires the presence of another so that the traumatic event can be related because the one who has experienced the trauma has not yet fully known the trauma's violence, and this may be causing the survivor to experience emotional pain" (p. 56). Similarly, in "'Let Me Tell You a Story': On Teaching Trauma Narratives, Writing, and Healing" (Spear 2014) Rachel N. Spear emphasizes that trauma narratives are uniquely designed to provide healing for the authors and that "one of the most acknowledged purposes of writing trauma narratives is that of healing" (p. 64). Drawing on Suzette Henke's book Shattered Subjects: Trauma and Testimony in Women's Life and Writing (Henke 2000), Spear claims that writing a trauma narrative serves "to restore the once-traumatized 'shattered subject'" and to articulate the unspeakable (p. 65). She stresses that traumatic memories are stored as fragments and not complete narratives and that the "act of trauma itself is often, if not always, associated with silencing, resulting in a lack of language and even a lack of narrative structure" (p. 62). She concludes that because trauma narratives are written for different reasons than other narratives and have different underlying processes, they should be treated differently from other kinds of narratives in non-fiction and fiction (p. 62). 
However, for one, responses to trauma can be varying. While some may find it hard to accept or speak about trauma, others are not so "shattered," and do not experience such a block. In the case of incest violation, many children do tell a non-offending parent or another adult about the abuse. Some adults believe the children and take strong measures to protect them while others disbelieve them or tell them not to talk about it. For example, in Don't: A Woman's Word (Danica 1988) Danica refers to telling both her mother and grandmother about the abuse but is not helped (pp. 25-26). Freud, infamously, was told many stories of paternal sexual abuse by his female patients but chose to conclude that these were based on false memories.

It is true that writers who write about trauma often acknowledge some purposes of their writing that could be seen as related to healing: to make sense of their emotional reactions, personality traits, and current life difficulties and to receive validation and support from the community. But to present authors of trauma narratives as healers and emphasize the healing value of their writings is to discount authors' accounts of ongoing suffering in their lives. While many books present the argument that writing about trauma is healing, for incest survivors the amount of healing experienced can be quite limited. Many incest survivors suffer from chronic mental and physical health problems, as chronic childhood trauma imposes severe stress on people's minds and bodies (Arruabarrena 2014; Herrenkohl et al. 2013). For example, Danica acknowledges that one of the reasons she wrote Don't was to attain greater clarity about her childhood and understand "why there was so much pain and difficulty in [her] life" (Danica 1988, p. 11). But she stresses in Beyond Don't: Dreaming Past the Dark (Danica 1996) that the large readership and media attention Don't received did not bring any resolution or heal the pain of her childhood: "It is a myth of mass culture that having one's story taken up by television bestows such attendant blessings that one's life is forever set apart and one is 'healed.' ... My real-life experiences did not guarantee salvation from poverty, and the burden of pain remained grievous" (p. 11).

Further, Spear refers to writers who write about trauma as "wounded healers," a term coined by Henri J.M. Nouwen to denote someone who "make[s] his [or her] own wounds available as a source of healing" (Nouwen 1972, p. xiv, quoted in Spear 2014, p. 67). On her view, trauma narratives provide the opportunity for readers to open their own wounds and experience some healing (p. 67). Similarly, Rak maintains that trauma narratives are designed to be catalysts of individual and social transformation, and help heal others and society (Rak 2003, p. 53). Rak relays that Danica stated in an interview that she "tried to write about pain in a way which had to be experienced by the reader and very carefully weighed ... to get the culture as a whole to look at what it is we are doing" (Danica 1993, pp. 79-80, quoted in Rak 2003, p. 60). Indeed, Danica hoped to make people take a greater interest in child welfare issues. Writers who write about upsetting life experiences and events naturally want readers to empathize and sympathize with them, and to feel moved to take a greater interest in the issues that they think are important. But this desire is different from a desire to help heal others and society. Danica illustrates how a view of her as primarily a trauma survivor and healer was detrimental to herself and her writing career:

At first I was appalled by people's reactions to Don't. People hurt and cried reading what I had written, which made me feel wretched. Instead of closing a chapter of my life, I was burdening others with it. For several years after the publication of Don't .... I would be stared at and whispered about, or approached by people who had horrific child-abuse disclosures they wished to share with me .... The problem was that I was no longer seen as a separate person and apart from the book ... . I began to feel erased by this unbearably narrow view of who I was. What about the rest of me? Growth, development, current projects, day-to-day issues and difficulties? (Danica 1996, p. 12)

Similarly, Roseann Lloyd, a poet who is also an incest survivor, is tentative about attributing substantial therapeutic value to her writing: "Writing ... doesn't provide me with all the answers. Some people say their computer is their best friend, but I haven't figured out how they get any satisfaction from hugging that monitor. Writing is sometimes a dead end" (Lloyd 1991, p. 73). 
She claims that in her first book of poetry she deliberately included poems about a variety of topics and explains: "I wanted the book to show the full range of my life, aspects of me as a citizen, mother, teacher, etc., not only as a survivor. I want my work to affirm the present lives that we have; many of us who were victims as children walk around looking like ordinary people" (p. 73). It's not so much witnesses to her trauma that Lloyd is seeking with her writing, but rather people that recognize her a regular human being, despite her harsh experiences of incest violation.

Further, Lloyd emphasizes the intellectual aspect of her writing process when she writes: "I've tried many approaches to writing about abuse. I decided I'd simply consider all poetic forms of Western traditions and those of indigenous people around the world as a treasure chest I could choose from. I experimented with many traditional forms, the power of chants and rhymes" (p. 72). Moreover, while she acknowledges that in her poems about incest violation she has sought "to convey the terror of living in a house with an abuser" (p. 72) and has wanted others to understand her experience, her "first reader is [herself]" (p. 73): "I write to make my life real to me" (p. 73). Thus, though Rak claims that the author of a trauma narrative "needs witnesses to make the story complete, and even real" (Rak 2003, p. 63), this is not true for Lloyd.

Like Lloyd, I want my own poems about incest violation to accurately capture and convey this life experience to myself as the first reader and also to others. Realism is no doubt an aim of many writers who write about their life experiences. In her poem "Insect is an Anagram for Incest" Lloyd compares the experience of incest violation to the experience of being invaded by insects (p. 72). I too have found this to be a useful comparison, and some of my poems about incest draw on insect imagery as well as animal imagery, such as my poem "Annie's Alphabet" (Nicki 2009, p. 69):

A is for ants crawling all over you

$B$ is for beetles doing the same

$C$ is for caterpillar inching up your leg

D is for Daddy Long Legs

$\mathrm{E}$ is for eel swimming between your legs

$\mathrm{F}$ is for feather tickling

$G$ is for gnat buzzing in your ear

$\mathrm{H}$ is for hugging

I is for icky

$\mathrm{J}$ is for stinging jellyfish

$\mathrm{K}$ is for kreepy $\mathrm{k} \mathrm{k}$ ?

$\mathrm{L}$ is for lemon juice

$\mathrm{M}$ is for Mom!

$\mathrm{N}$ is for sharp nail

$\mathrm{O}$ is for octopus squeezing you tight

$\mathrm{P}$ is for prickly cactus

$Q$ is for quietly

$\mathrm{R}$ is for roll over

$\mathrm{S}$ is for sticky

$\mathrm{T}$ is for terror

$\mathrm{U}$ is for ugly

$\mathrm{W}$ is for wiggling

$\mathrm{X}$ is for $\mathrm{x}$-rated

$\mathrm{Y}$ is for yell caught in your throat

$\mathrm{Z}$ is for zzzzzzzz

While in "Annie Alphabet" I aim to convey the idea that the horrible experience of incest can be as formative as learning one's first language, in "Adult Incest Survivors" (Nicki 2009, p. 70) I stress that despite the traumatic impact of incest, survivors can vary widely in terms of their responses to the 
abuse and the choices that they make in adulthood. Influenced by Lloyd, I want readers to recognize that incest survivors are not only people who have survived chronic trauma:

A is for Angela who married a batterer

$B$ is for Brenda who never left home

$\mathrm{C}$ is for Clair who married at sixteen

$\mathrm{D}$ is for Diane who went to another country

$\mathrm{E}$ is for Elizabeth who became anorexic

$\mathrm{F}$ is for Fiona who became a religious fanatic

$\mathrm{G}$ is for Georgia who became a prostitute

$\mathrm{H}$ is for Hannah who became celibate

I is for Iris who became a philosopher

$\mathrm{J}$ is for Jayne who became mute

$\mathrm{K}$ is for Kathryn who became a social worker

$\mathrm{L}$ is for Linda who became a teacher

$\mathrm{M}$ is for Mary who became a musician

$\mathrm{N}$ is for Nancy who became a librarian

$\mathrm{O}$ is for Octavia who became a poet

$P$ is for Priscilla who raised two children

$Q$ is for Queen Anne who ruled a nation

$\mathrm{R}$ is for Rachel who rode horses

$\mathrm{S}$ is for Sarah who sold appliances

$\mathrm{T}$ is for Tanya who worked as a server

$\mathrm{U}$ is for "Ugly Duckling" who never could believe in herself

$\mathrm{V}$ is for Viola who became a painter

$\mathrm{W}$ is for Wendy who became a writer

$\mathrm{Y}$ is for Yvonne who worked in a fishery

$\mathrm{Z}$ is for Zelda who wanted to save every miserable girl

In both poems I deliberately use a child-like voice and vocabulary to convey the innocence of child victims of incest rape, thus challenging a societal view of children as willful seducers displaying an "Oedipus complex." This is a technique used in Christine Stark's book Nickels: A Tale of Dissocation (Stark 2011) on incest and other forms of child abuse; the book presents these experiences from the viewpoint of the child survivor. In Stark's book she compares her rapist's penis to a snake (p. 5), a comparison arising from a child's lack of knowledge about sex and sexual anatomy. Influenced by Stark's depiction, I have used snake imagery in some of my later writing about incest, such as in my poem "Nightcrawlers" (Nicki 2013):

1.

When you are just a young girl

without sex education or experience

you don't really know what a penis is

The first time a penis came close to me it was my father's in the dark at night

I thought, large worm, snake

the worm a boy threw down my shirt

to make me scream

the snake that caused Adam and Eve to lose paradise

taught in catechism class

I reflected, this penis is a worm-thing, snake-thing

that is part of a human body 
asked how it was able to move in mid-air

without inching along the ground

He explained, "Remember the story

about the snake charmer:

sometimes a little girl is so beautiful

she can make a snake come out from hiding"

I worried about the large worm entering my body

had seen worms broken in two

that continued to live and move

thought that after the worm withdrew

a part of it might still be in me

feeding off and ruining my insides

2.

In the art therapist's office I take a chunk of grey clay

and shape with it all the penis times

that touched and entered me as a child

I make dozens and dozens of worms

am afraid to count them

a huge pile of small ashen corpses

The art therapist tells me to take them

to the river and watch them dissolve

I carry them in a plastic bag

and dump them in the water

squishing them between my fingers

but they don't dissolve

there are too many

they hover near the bank too visibly

I am worried some people will see them

ask me what I am doing

and when I explain that I am doing a grief ritual

they will wonder why there are

so many little grey snakes

and who it is that died

In the second part of the poem I emphasize, like Danica and Lloyd, that processing traumatic experiences has limited benefits. I show the severe inadequacy of mental health services to alleviate the emotional suffering of incest survivors as their suffering is exacerbated by social marginalization and the social denial of incest. The survivor is told to dig up and release all her suffering only to feel alone and overburdened with this suffering in a society where incest violation is a taboo topic and survivors cannot expect to experience social inclusion (Nicki 2015). In another poem, “Therapist" (Nicki 2009, p. 81), I convey that presenting a narrative of trauma to a psychotherapist results in limited healing and human connection:

You pay 22 dollars out of pocket

the therapist's face like a round clock

the minutes that tick away

miniscule steps that reach fifty

and a buzzer goes off

she has forgotten my story 
Similarly, cultural theorist and poet Judy Grahn claims in an article "March to the Mother Sea: Healing Poems of Baby Girls Raped at Home" (Grahn 1991, p. 133) that art and psychotherapy have had only some roles in her healing, and emphasizes the contributions of feminism and spirituality:

I cannot say that art alone heals me ... It has been the conscious journey of therapy, ... my well-trained and sensitive lesbian-feminist therapist and prodigious efforts on my own behalf ... Conscious art, conscious spiritual rite and conscious healing, the coupling of consciousness and unconsciousness toward the end of healing in a female-centered psychological and spiritual context-that is what has worked for me.

Grahn discusses her poetry sequence "March to the Mother Sea" (Grahn 1990) and the line: "O Mother rock me, rock me down to the deep green sea where I can be with the jellyfish queens" (Grahn 1991, p. 133). She states that the line "is based in the psychological image of baby girls banding together to march into the Mother Sea" (p. 113). The girls are not passive victims but show "courage and involvement" (p. 113) in seeking the protective power of "the jellyfish queens." She adds, "The jellyfish may look vulnerable but she is very self-sufficient and doesn't allow anyone to mishandle her. She stings like fire, and ... has venom behind her sting" (p. 117). Further, she states that the "Mother Sea represents a great natural force infinitely larger than human society [and is] a metaphor of justice, involvement and large perception" (p. 119). Clearly, some poems about incest, like Grahn's, are not designed to enact secondary trauma in readers but rather are conscious attempts to articulate an alternate feminist spirituality and faith in the protecting power of a divine Mother.

Like Grahn, feminist spirituality has played a significant role in my healing from incest violation and some of my poems on this subject, influenced by Grahn's, express challenges to patriarchy. For example, my poem "Man with Five Penises" (Nicki 2009, p. 19) was designed to challenge the patriarchal power of the penis as a tool of dominance and violence. I present the phallus as something playful and associate it with music: "The man with five penises/I want to play them like a harp/I want to suck on each one/like a saxophone and make/original music" (p. 19). I also associate it with flowers and snakes, drawing on ancient Greek mythology and art which presents positive images of snakes: "I want to hold them like a bouquet/I want them to surround my head/like beautiful snakes/hissing only sounds of love/and adoration/I want the snakes to travel down/and circle my body/my shoulders, breasts, stomach/buttocks, legs, feet" (Nicki 2009, p. 19). I read this poem in a public literary reading. While some male and female listeners misinterpreted this poem as primarily erotic, some men, to my delight, said that the poem made them feel that male genitalia were more a source of play.

Further, in my poems "hurricane thomas: a traumatic re-enactment" (Nicki 2012, pp. 70-77) and "Vagina Dentata" (Nicki 2012, pp. 78-79), which are also responses to my experience of incest violation, I seek primarily to challenge sexist thinking about female genitalia as a passive hole or impotent flower, and refer to forgotten ancient matriarchal societies. In "hurricane thomas," in describing an intimate encounter, I write: "these lips of hers ... like a loose begonia or rose?/his tongue long inside tells her differently/seeking its own rapture its own aphrodisiac/these lips the opening of a new world...pink river pink ocean pink time travel ...an ancient pagan village" (pp. 71-73). In "Vagina Dentata" I write: "There was a time when women/actually had these teeth/an evolutionary adaptation of female warriors/not just a morbid fantasy, a myth" (p. 78). I argue that the teeth stopped growing in newborn girls because of the spread of the tooth fairy myth and idealization of "gentle and benign" (p. 78) femininity, and end with a spiritual invocation to create more tooth-armed women, who can protect themselves against rape.

As the above discussion on Grahn's poems and my own poems shows, incest narratives can be less narratives of trauma and healing than narratives of resistance and calls for social change. Notably, in "Recovering our Stories: A Small Act of Resistance," Costa et al. (2012) explore how personal stories from people with lived experience of trauma and mental health challenges have been co-opted and misrepresented by researchers for academic gain, and to produce accounts that are consistent with well-respected mainstream scholarship. Literary theorists, when presenting incest narratives in 
research and making claims about these, need to pay close attention to authors' statements. They need to be open to storylines other than that of healing and recovery so that they don't misrepresent the narratives or neglect those narratives that depart more significantly from the assumed story frame. When incest narratives are seen primarily as recovery narratives, there is no need or interest to explore "just another incest recovery story." For example, when I told a literary theorist who specializes in trauma narratives that I had written some poetry books that are, in part, about incest, she expressed no interest in the books, and said that she really appreciated Danica's book Don't. Literary theorists should also be mindful about various intellectual and aesthetic influences on authors, including other writers on incest, as discussed in my own case. Incest narratives can be viewed as displaying not only resistance but also respect and solidarity toward other authors, as can be found in narratives about other forms of trauma and social injustice.

\section{Teaching Incest Narratives and "Wounded-Healer Pedagogy"}

Incest violation is not a rare occurrence. Based on reports of Child Protective Services in the United States for the period of 2009-2013, 1 in 9 girls and 1 in 53 boys under the age of 18 are sexually abused by an adult, and the perpetrator is most often the father (www.rainn.org/statistics/children-and-teens). But teaching incest narratives can be challenging for instructors because it is a marginalized topic in society and education, and covered only in courses on trauma or ones that cover the topic of sexual violence. Students can bring misinformation and stereotypes to the classroom. Rak states that when she taught Danica's book Don't as part of a fourth-year course about autobiography and subjectivity, several students felt silenced and overwhelmed by the book and could only comfortably engage with it after they found reviews and interviews (Rak 2003, p. 66). The silence she experienced is not surprising. Students may not have any first-hand or second-hand familiarity with incest violation or believe that it is a very rare occurrence. As Ross E. Cheit et al. report (Cheit et al. 2010), newspaper journalism gives a false representation of child sexual abuse, and tends to emphasize cases of extra-familial child sexual abuse involving celebrities or multiple victims. Further, many people who have experienced this form of abuse may have suppressed these memories because of their traumatic nature and the lack of public concern and discussion about incest violation. People may have much difficulty accepting that their parent or other family member is like the "sick," "monstrous" child sex offenders depicted in the media.

Moreover, students who are incest survivors may experience not so much shock from reading works like Don't but exhilaration and validation in finding themselves not alone in their childhood experiences. But they may fear that in talking about the subject they will inadvertently reveal this fact and experience unwanted responses from classmates. Writer Marie-Elise Wheatwind shares that when she was a student she wrote a short story about incest from the third-person and was afraid to share the story with her classmates: "I was terrified ... they wouldn't understand it and even more afraid they would ... and demand details me, more descriptions of the things that I didn't want everyone to see" (Wheatwind 1991, p. 12).

When I first taught narrative writing about incest in a multidisciplinary health ethics course, some students expressed hostility toward the authors and saw them as man-haters, just as some interviewers had responded to Danica after the publication of her book Don't (Danica 1996, p. 49). No one in my class openly questioned the veracity of the writers' claims as they had learned about the prevalence of domestic violence and child sexual abuse in other classes in health sciences. However, some did express the view that children who are subject to sexual experiences with adults freely seek out these experiences. The expression of this view can be stressful and demoralizing for incest survivors in the classroom. Thus, for this reason and those mentioned above, it is important to do some groundwork before starting a discussion on a text about incest and adopt a pedagogical approach that is inclusive of incest survivors.

An instructor should discuss: stereotypes of incest survivors, such as survivors as willful child seducers or as children of poor, working-class parents with drug problems; criteria needed to be met 
for informed consent in sexual activity; the statistical estimates and high occurrence of incest and extra familial forms of sexual violation; and the medicalization of and social discrimination against incest survivors (discussed in Nicki 2016a). Instructors should acknowledge the possible presence of male, female, or trans incest survivors of any race and from any cultural or class background in the classroom to challenge stereotypes based on gender, race, culture, or class. Further, instructors could share some poems from Avery Guess' educational chapbook (Guest 2016) on her experience of chronic child abuse and institutionalization in a psychiatric facility. This work challenges the view of incest survivors as willful seducers and insightfully presents the sexual relationship that her father forced on her as a kind of child marriage. Further, it compellingly depicts severe family dysfunction as the cause of her severe emotional suffering and forcefully challenges the psychiatric view of this suffering as the result of biochemical imbalances. The reader is thus led to adopt what PhebeAnn M. Wolframe calls a "mad reading of the text," where the reader does not assume the validity of a psychiatric lens, or perceive someone emotionally struggling as unreasonable, with mental health problems in no relation to a life situation (Wolframe 2013, p. 4).

Spear claims that educators should teach trauma narratives through what she calls a "wounded healer pedagogy" where "students are positioned as being in need of healing-by teachers, by texts, by courses" (Spear 2014, p. 68). On her view, when teaching these narratives educators should promote the values of compassion, mutual respect, and sensitivity. They should acknowledge to the class that everyone has wounds to some extent and is in need of healing and that stories covered in the course are life experiences that people in the class may share. She mentions that a student may disclose being a survivor of child rape (p. 69). However, she doesn't discuss any specific pedagogical strategies that an educator could adopt to address this disclosure, stating that when students disclose personal stories of trauma there are "no rules for how teachers should react" (p. 70). She states that she invited speakers from the Counselling Center and contacted a campus case worker when students appeared to need support (p. 71).

Certainly, compassion, mutual respect, and sensitivity are essential values to promote in a course on trauma narratives. And reminding students of campus resources reflects a caring attitude in an educator. Further, stories can serve as, importantly, catalysts for healing, or individual growth and social transformation. And if students do experience individual growth from reading and discussing trauma narratives, this is certainly a benefit. But it can be difficult for students who are incest survivors to experience healing and support if when stories about incest are covered an educator does not adopt a pedagogical approach that is inclusive of incest survivors. Without this approach, a discussion about an incest narrative could be wounding and alienating for incest survivors. In social parlance, incest survivors are thought, problematically, to be in special need of healing (See Nicki 2016a, p. 206). Notably, writer Roseann Lloyd states, "I'm always keyed up at readings ... . There's an extra level of fear when I'm reading poems about incest because of all the myths around it, and the vulnerability" (p. 74). Spear claims that the possibly that a student might disclose a history of incest is "a possibility that augments instructors' apprehensions in teaching trauma narratives and stifles selection of course content" (p. 69). Why would instructors be especially worried about a student disclosing a history of incest? How is a life experience of incest different from other traumatic life experiences?

A large problem with positioning students as wounded healers in an English literature course on trauma narratives is that students would not typically be primarily taking such a course to be healed but to learn more about literature about trauma and social justice issues and improve their skills in reading, critical thinking, and writing. Given that incest survivors are seen reductively in society as severely wounded and primarily in need of mental health treatment, Spear's "wounded healer pedagogy" brings the risk that both authors and students who are incest survivors will be treated more as wounded people than writers.

For example, a few years ago I took part in a training program to become an expressive writing therapist; the program employed what might be called a "wounded healer pedagogy." In a homework assignment the director asked us a series of questions related to the theme of loss and vulnerability 
which we were to answer in the form of poems. My poems were about growing up in an abusive home and being sexually violated. In the next class he asked me to present my poems. I was really wanting to present them as I had worked hard on them and was pleased with their metaphors, imagery, and ideas. But after I read the poems he said, in an annoyed tone, that my poems were "very intense" and that, as he wasn't a trained therapist, I needed to seek outside support. Most of the class fell silent, and he didn't encourage a discussion of my poems, (though a few students treated me as a writer and later privately emailed me positive feedback on the poems' metaphors and imagery).

A week before, in response to similar writing prompts, another student had written and presented poems about two miscarriages and related frustration and depression. Why was I, but not this poet, directed to seek private therapy? Unlike her poems, my poems did not express despair or disorientation but rather self-insight and self-empowerment. One of the poems relayed that as a young girl I had cut off the hair of my princess doll in an attempt to protect her: "I turned her into a knight, conjuring an invisible fortress around her/guards, centurions, a drawbridge." This poem was inspired by a passage in Grahn's poetry sequence "March to the Mother Sea" where she associates femininity with danger and refers to altering a doll: "My pretty pink dress is mashed/and torn ... /I will never wear pink when I grow up / . . My pretty pink dress is poked and torn, /I'm scared to say why. / ... I smashed the baby dolly again in my games today. /Her dress so pink and pretty/I tore and threw away" (Grahn 1990, p. 10). Poems about incest often include challenges to sexism and my poem "Pink Balloons" (Nicki 2016b) below is both a response to incest and the gender bias underlying the instructor's reception of my work:

The poetry leader tells us

to write about childhood experiences

He shares his poem about

his love for baseball

I write energetically about child rape

the ways I tried to love myself as a girl

When it's my turn to share

he pops my pink balloon

says this experience must be locked in a room

with a professional therapist

I look at his blue balloon

the string held tightly in his hand

On it he has written

in thick black marker

"Pink balloons are dangerous"

Feeling excluded by the instructor I decided to withdraw from the program. I told him that I was withdrawing because he and the students seemed uncomfortable with my life experiences, which my writing would continue to draw on. He said that withdrawing was a good idea and that students might feel overwhelmed by the content of my poems. Spear writes, after quoting a few lines of an incest narrative by Dorothy Allison (Alison 1992): "At times, trauma may overpower the story, and it may even overwhelm its readers" (p. 74). Rak and Spear claim that when this happens silence and a lack of intellectual engagement can be an appropriate response as a way of bearing witness to trauma. But who decides when trauma overpowers a story? If a reader feels overwhelmed by a story, does that mean the trauma overpowered it? And if a class doesn't have the words to respond to incest trauma and a student incest survivor, isn't it the role of the educator to find strategies to ensure the inclusion of all students regardless of differences in life experiences? 


\section{Trigger Warnings and Survivors of Chronic Childhood Trauma}

Some professors give students trigger warnings when they judge that course material on trauma might overwhelm students who have experienced the same form of trauma. Students can then mentally prepare to receive the material and not experience the shock of an unexpected reminder of trauma. Trigger warnings are typically given when the subject matter presents experiences like rape and other forms of violence. Disability scholars justify the practice as serving to make course material more accessible (Carter 2015). Carter (2015) claims that those who oppose trigger warnings reinforce the individual model of disability, in implying that educators don't need to take into account the needs of students who have been traumatized and only ensure that they are directed to mental health resources on campus (Carter 2015, p. 6). She emphasizes that proponents of trigger warnings understand that these aren't perfect and won't prevent people from experiencing some distress in being reminded of traumatic experiences (p. 10). Their value is that they reflect a recognition of students as "whole persons ... [with] emotions, struggles, and lived experiences" (p. 10).

However, the way trigger warnings are typically used, in treating only certain topics as inherently triggering, do not ultimately reflect an appreciation of students as distinct individuals with distinct life histories. As some theorists note (Kafer 2016, p. 16; Freeman et al. 2014), trigger warnings are flawed because students can be triggered by material and other phenomena that would seem unobjectionable, such as smells or sounds. Carter herself concedes, "there is no way to predict what may trigger one student or another" (p. 13). In the case of survivors of incest and, generally, survivors of chronic childhood trauma, who typically endured upsetting events on a regular basis, there can be so many reminders of traumatic life experiences, such as interactions in the present with family members and childhood friends; domineering personalities and material objects that remind one of the offender(s) or those who colluded with him/her/them; locations that one experienced with the offender(s); and the many, various activities that one took part in with him/her/them (e.g., driving, cooking, sport activities, and camping). Having negative associations with so many activities can make it difficult for survivors to enjoy them, and not be reminded of their childhoods, and mentally and physically re-experience past trauma. Further, functional familial relationships, whether encountered in real-life, read about in literature and text books, or seen in films, can also be triggering as one is forced to note a contrast, and the harms that one suffered and possibly continues to suffer.

As Kafer notes, "casting certain topics as inherently triggering can too easily become a means of banishing [them] altogether" (p. 15). It serves to reinforce the allocation of these issues and experiences to the private counselling spaces of mental health professionals. Ultimately, it reinforces a lack of inclusion of people with histories of family dysfunction and reflects a poor understanding of their life struggles and of how they are excluded and wounded in different ways. Trauma has a greater negative impact if there is a poor response, such as invalidation and a lack of support. As Aphrodite Matsakis argues, survivors of chronic childhood trauma can experience "secondary wounding" when people give unsupportive responses (Matsakis 1996, pp. 90-100). Notably, proponents of trigger warnings concede that giving trigger warnings is only one way to approach sensitive material and that educators need to employ a variety of strategies that help students engage with it and manage its effects on their minds and bodies (Carter 2015, p. 10). For example, if an instructor facilitates a discussion on the subject of chronic childhood sexual abuse without any challenge to myths or stereotypes of incest survivors, survivors may be reminded of other occasions of exclusion and wounding and feel upset. Student survivors of different forms of sexual violation have reported that they feel strong negative feelings when the topic of sexual violence is not properly introduced or contextualized or is discussed very abstractly or casually, without any acknowledgement on the part of educators of the possible presence of survivors in the classroom (Konradi 1993, p. 14). Such lack of acknowledgment may be experienced as exclusionary and dehumanizing, and reminiscent of other unsupportive responses. Survivors of chronic childhood trauma can really welcome the opportunity to talk about their experiences in communal settings, as shown by the global popularity of the 12-step support group of Adult Children of Alcoholics and/or Dysfunctional Families shows (http:/ / acawsoec.com/countries). Many survivors 
go daily to meetings. Though they can feel emotional pain and agitation recounting their experiences and listening to the experiences of others, they also can feel tremendous relief and joy in knowing that there are others with whom they can share without fear of judgment and rejection. In classroom discussions on narratives of chronic childhood trauma, survivors can be triggered to a tolerable degree when they feel survivors are being treated with respect, as any demeaning attitude can be associated with the chronic child maltreatment, and add to survivors' psychological burden of negative life experiences.

\section{Supporting Student Survivors of Chronic Childhood Trauma}

Students with histories of chronic childhood trauma should be identified as a minority group facing disadvantages who require much more than the small gesture of inclusiveness reflected in the use of trigger warnings. Like student members of other minority groups, they need informed mentoring from professors. These students may have had no substantial positive experience with a benevolent, protective adult, and so may have a great fear and dread of authority figures like professors. Wisechild (1988), a survivor of chronic childhood abuse, echoes my experience as a graduate student when she states that she was afraid of her professors and couldn't "seem to relax around them like other students who engaged them in casual conversations" (p. 5). My great fear and distrust combined with my labile mood was a significant obstacle as I was, unlike other students, unable to network with professors and secure enthusiastic mentors. When I did speak to professors, I would seem very nervous and uncomfortable or somewhat hostile and impolite in forcefully trying to mask my emotional discomfort. Despite having anxiety and concentration problems, I was able to get high grades. But while some of my professors appreciated my intellectual ability, they didn't feel comfortable with me. When I needed letters of references for applications for fellowships and asked professors for them, they would tell me to ask someone else or these requests were met with merely a sense of duty.

In order to make a professor be positive and supportive toward a student who is a survivor of chronic childhood trauma, and not simply treat the student as having a bad personality, a professor would need to know and appreciate the student's life narrative. This would require that the professor be open to the personal, believe the student's account of his/her life, possibly challenge in himself/herself any stereotypes about survivors of childhood trauma survivors, and understand the severe psychological burden that chronic childhood trauma produces. Further, the professor would also have to understand that people respond in different ways to trauma and can have different buffeting factors, or internal and external resources, so that if a survivor has some areas of high functionality this doesn't mean the person hasn't experienced severe trauma. For example, because I was able to obtain a Ph.D. some have questioned whether I am a survivor. To help professors better support survivors and promote their academic success, health and counselling services centers at colleges and universities should offer workshops to professors and relevant staff on the life struggles and psychological challenges of survivors of chronic childhood trauma, which include an exploration of misinformation and stereotypes.

Carter (2015) argues that students with psychological disabilities (a group that includes student survivors of chronic childhood trauma) withdraw from institutions of higher education because they don't access disability services (p. 9). She refers to a study by Collins and Mowbray (2005) on higher education and psychological disabilities which found that $86 \%$ of students with psychological disabilities leave before they finish their degree because they do not access disability services and receive institutional accommodation (p. 9, quoted in Collins and Mowbray 2005, p. 308). But this study does not show that the main reason these students drop out is a lack of accommodation and institutional support, and only that many don't access disability services. Even if they had accessed disability support services, many still might not have completed their degrees.

Many survivors of chronic childhood trauma are foster youth. In North America, support for children in foster care ends between ages 19-21, depending on the state or province. Only 20 percent 
of college-prepared foster youth enrol in post-secondary education and less than 5 percent finish a degree, because of practical or system barriers (Unrau 2011, p. 17). For example, based on a study by Pecora et al. (2006) less than one-third of youth exiting foster care have important resources such as money, a driver's license, and household necessities (Unrau 2011, p. 18). Without a guardian they have no one to co-sign a loan or lease, and thus have trouble finding housing (Unrau 2011, p. 18). Recognizing that foster youth are an underserved student population, some academic institutions have waived tuition or offer bursaries for current or former youth in foster care. For example, in British Columbia, in 2013 Vancouver Island University waived tuition for former foster children (Watts 2016). Since then, 11 additional post-secondary institutions have either waived tuition or offered bursaries to current or former youth in care (Watts 2016). Western Michigan University has taken a greater step in supporting youth who have aged out of the foster care system by establishing the Seita Scholars Program at Western University which provides financial, academic, and personal support. Scholars are directed to see themselves as experts on the lived experience of foster care and there is an official student organization called "Foster Youth and Higher Education" which promotes community and solidarity among members (Unrau 2011, p. 19). Former foster youth, or Seita Scholars, are assigned a Campus Coach who is available through email, phone and face to face meetings and, like a supportive parent, can be reached at any time for emergencies (Unrau 2011, p. 18). While many survivors of chronic childhood trauma have not been in foster care, a program like the Seita Scholars Program could include other students who are severely lacking in adult mentoring and support.

Further, as I have argued elsewhere, survivors of chronic childhood trauma may lack important life skills like relationship skills because of a lack of parental support and mentoring (Nicki 2016a, p. 234). Health and counselling services centers offer workshops that strengthen some life skills, such as workshops on how to manage stress, practice mindfulness and balance different aspects of one's personal, school, and work life. But it would be helpful if there were workshops that strengthen interpersonal skills such as workshops on non-violent communication, which could benefit the general student population. Further, as many survivors of chronic childhood trauma have benefitted from the twelve step peer-run support group Adult Children of Alcoholic and/or Dysfunctional Families, it would helpful for survivors if this group was started and made available on campuses. This kind of group is typically not found on academic campuses as survivors are directed to turn to counsellors and psychiatrists for support. These may provide some degree of connection and support but this peer-run support group, like the student organization "Foster Youth and Higher Education" at Western Michigan University, can better reduce feelings of isolation and separateness. Students should also be encouraged to form an organization like "The Hamilton Mad Students Collective: A Peer Support and Advocacy Community" formed in 2012 (http:/ / www.hamiltonmadstudents.ca/about). This organization embraces non-medical understandings of emotional suffering and problems in social living and provide supports for students experiencing barriers and discrimination based on psychological disability or sanism.

\section{Survivor-Inclusive Pedagogy}

In ensuring that survivors of chronic childhood abuse are truly included in higher education it is not only important that student services address their needs, but also, as in the case of other minority groups, that curricula include their perspectives and life experiences. For example, it is important to include authors who are survivors of chronic childhood trauma not only in English literature courses on trauma narratives, but also in more general English literature courses. These courses could include literature by survivors that presents their experiences and perspectives instead of, for example, literature that depicts children as willful seducers, such as the canonical work Lolita, and serves to invalidate the experiences of survivors. Fowles (2014) rightly criticizes the exclusion of works by survivors of incest like Don't from the literary canon:

We like to believe the canon is a product of human experience, yet rape-in all its pervasiveness-rarely finds itself there, especially when told in the authentic, non- 
appropriated voice of the survivor ... . If we cast out "women's books" like Danica's to an oft-forgotten therapeutic or feminist corner, we fail, culturally, to understand their collective insight into who we are and how we live. We want to believe that her story is isolated and extreme, that rapists are simply inhuman monsters, but the truths she conjures are universally applicable. And sadly, they are just as true now as they were in the over twenty years since Don't's publication.

Further, in programs in counselling, social work, clinical psychology, and medicine students should be given first-person narratives of survivors, which refer to wide ranging aspects of their lives, and trained in how to interact with survivors in a way that does not reflect stereotypes, judgment, and over-medicalization. While many survivors suffer from chronic mental health problems, survivors should not be regarded as doomed to lives of endless suffering and curricula should include research that emphasizes life trajectories of success, such as that of Thomas and Hall (2008). As Thomas and Hall note, healing trajectories can be quite variable; although survivors typically struggle with depression and anxiety, they can be successful in such areas as parenting, relationships, work, and community service. Further, since survivors of chronic childhood trauma may have experienced incest, clinicians and instructors should be knowledgeable about various potential implications for sexual development under extreme duress (See Nicki 2016a, pp. 230-32). Instructors in any course in which sexuality is covered as a topic should possess this knowledge to ensure they have an inclusive pedagogy toward student incest survivors.

For example, while doing course work in graduate studies, I took a seminar course on sex and sexuality. I was twenty-three at the time, and still processing the many years of abuse in my family of origin. I was seeing a psychiatrist who was helping me to integrate, specifically, my experiences of childhood sexual violence, and bringing up these memories were causing me to feel some negativity about sex and sexual relationships. Several of my classmates expressed enthusiastic views about sex and sexual relationships and I was feeling very anxious about participating and fitting in with my peers. One day when I managed to contribute to a class discussion, I conveyed some anxious feelings about sex which were judged critically by the professor and some students as sex negative. I met with the professor to try to explain why I was having difficulty feeling positive about sex and alluded to my experience of sexual victimization, but the professor wasn't receptive and I found it hard to be understood. I wanted the professor to intervene in some way in class so that I could feel I had a valid perspective and equal right to contribute to class discussions. In this kind of situation, a professor could acknowledge that people can have different levels of interest in sex and sexual relationships, which can depend on their personal values and life experiences, such as that of sexual violence. A professor could state that there may be survivors of sexual violence, including incest survivors, in the class and that these people might not at this time be feeling sex positive.

\section{Conclusions}

Because survivors of chronic childhood trauma have been medicalized and relegated to the realm of private mental health care, their rights and interests have been rendered invisible in public educational settings, whether as assigned authors in courses or students. Professors aim, in good faith, to be inclusive of survivors when having their students read an incest narrative in a course on trauma narratives, emphasizing the values of respect and sensitivity in a class discussion on it, giving a trigger warning, and reminding students of counselling services. But this approach toward survivors, which emphasizes their woundedness and otherness, is reminiscent of their life experiences of lacking nurturing homes. It keeps them outside the hearth of education, looking in on a wealth of knowledge systems that excludes their expertise and perspectives. Unfortunately, despite the efforts of mad studies scholars and activists, who promote non-medical understandings of problems in social living, research on chronic childhood trauma and related psychological disability continues to be largely controlled by clinically trained investigators seeking to further develop second-hand observational knowledge. As Jones and Brown (2013) note, this contrasts with research on physical disability, which 
includes first-person perspectives on disability and the assumption that disability is only one aspect of a person's identity. In the field of disability studies, which scholars in other fields are increasingly drawing on, there is no belief that only people with highly specialized training can understand and support people with physical disability. Rather, the physically disabled are recognized as having expertise on their own life experiences and presented as capable of understanding and supporting each other through networks and organizations that advance their rights and interests. Laudably, programs like the Seita Scholars Program for foster youth reflects a recognition that survivors of chronic childhood trauma are experts on their lived experience and are able to support each other and promote their common interests.

Some psychology professors have started to recognize the expertise of survivors of chronic childhood trauma on their lived experience and invite them as guest lecturers in classes for clinical psychology trainees. For example, the Facebook group "PD in the Bin," a group of survivors of chronic childhood trauma that seeks the abolition of diagnoses of personality disorders, was recently contacted by a psychology professor looking for guest lecturers with lived experienced with a personality disorder diagnosis and a critique of the pathologization of survivors. Further, another psychology professor contacted the group looking for people with lived experience of the diagnosis of borderline personality disorder, to interview for a project that aims to challenge the pathologization of survivors and emphasize their resilience and personal strengths. These acts of inclusion are a good start. But there needs to be a full paradigm shift in how survivors of chronic childhood trauma are viewed, so that they are seen as potential colleagues and collaborators, and not simply temporary guest lecturers or research subjects. As survivors are experts on the lived experience of chronic childhood trauma, researchers who wish to conduct interviews on them should invite them to be collaborators and co-authors when they have relevant academic credentials, such as a Ph.D. in a relevant area in humanities or social sciences.

In the literary realm, mainstream publishers can help improve the social status of survivors by including writers who explore chronic childhood trauma. Encountering a book like Don't can be hard for readers to absorb in part because its appearance is so unusual; narratives on incest rarely rise to public attention, and, seen reductively as women's stories, only small independent feminist presses are open to publishing them. It is, however, heartening that the author and incest survivor Avery Guess has been awarded prestigious fellowships such as a National Endowment for the Arts (NEA) fellowship for poetry. One can only hope that other award granting agencies will expand their criteria for literary excellence and nurture, support, and level the playing field for writers who explore chronic childhood trauma.

The social status of survivors is also ameliorated when journals other than ones in medical humanities include trauma narratives to deepen readers' understanding of social problems. For example, The University of Pennsylvania Law Review (Stark 2010) symposium on trafficking in sex and labor begins with Christine Stark's memoir entitled "Run." This inclusion was praised by Serota (2011) in an article published in a subsequent issue of the journal which argues that creative writing should be given an important role in legal scholarship. His article is especially encouraging as he presents Stark more as a sophisticated writer than a healer and details the rhetorical devices that she employs in relaying the individual and social impacts of human trafficking. Hopefully, more law journals will include fine creative writing on childhood sexual abuse.

Conflicts of Interest: The author declares no conflict of interest.

\section{References}

Alison, Dorothy. 1992. Bastard Out of Carolina. New York: Penguin Group.

Arruabarrena, Ignacia. 2014. Maltreated Children. In Handbook of Child Well-Being: Theories, Methods, and Policies in Global Perspective. Edited by Asher Ben-Arieh, Ferran Casis, Ivar Frones and Jill E. Korbin. Dordrecht: Springer Science and Business Media, pp. 2669-96.

Caruth, Cathy, ed. 1995. Trauma: Explorations in Memory. Baltimore: Johns Hopkins University Press. 
Carter, Angela M. 2015. Teaching with Trauma: Trigger Warnings, Feminism, and Disability Pedagogy. Disability Studies Quarterly 35. Available online: http:/ /dsq-sds.org/article/view/4652 (accessed on 10 August 2017). [CrossRef]

Cheit, Ross E., Yael Shavit, and Zachary Reiss-Davis. 2010. Magazine Coverage of Child Sexual Abuse, 1992-2004. Journal of Child Sexual Abuse 19: 99-117. [CrossRef] [PubMed]

Collins, Mary Elizabeth, and Carol T. Mowbray. 2005. Higher Education and Psychiatric Disabilities: National Survey of Campus Disability Services. American Journal of Orthopsychiatry 75: 304-15. [CrossRef] [PubMed]

Costa, Lucy, Jijian Voronka, Danielle Landry, Jenna Reid, Becky Mcfarlane, David Reville, and Kathryn Church. 2012. Recovering our Stories: A Small Act of Resistance. Studies in Social Justice 6: 85-101. Available online: https:/ / brock.scholarsportal.info/journals/SSJ/article/view/1070 (accessed on 7 February 2018).

Danica, Elly. 1988. Don't: A Woman's Word. Charlottetown: Gynergy Books.

Danica, Elly. 1993. An Enormous Risk but It's Got to Be Done. Interview by Janice Williamson. In Sounding Differences: Conversations with Seventeen Canadian Women Writers. Edited by Janice Williamson. Toronto/ Buffalo and London: University of Toronto Press.

Danica, Elly. 1996. Beyond Don't: Dreaming Past the Dark. Charlottetown: Gynergy Books.

Freeman, Elizabeth, Brian Herrera, Nat Hurley, Homay King, Dana Luciano, Dana Seitler, and Patricia White. 2014. Trigger Warnings Are Flawed. Inside Higher Education. Available online: https:/ / www.insidehighered. com/views/2014/05/29/essay-faculty-members-about-why-they-will-not-use-trigger-warnings (accessed 11 October 2017).

Fowles, Stacey May. 2014. Talking to Elly Danica about Don't: A Woman's Word. The Toast, November 17. Available online: http:/ / the-toast.net/2014/11/17/elly-danica-dont/ (accessed on 10 August 2017).

Guest, Avery. 2016. The Patient Admits. Chicago: Dancing Girl Press.

Grahn, Judy. 1990. March to the Mother Sea: Healing Poems of Baby Girls Raped at Home. Oakland: Lavender Rose Productions.

Grahn, Judy. 1991. March to the Mother Sea: Healing Poems of Baby Girls Raped at Home. In She Who Is Lost Is Remembered: Healing from Incest through Creativity. Edited by Louise M. Wisechild. Seattle: The Seal Press, pp. 110-20.

Henke, Suzette A. 2000. Shattered Subjects: Trauma and Testimony in Women's Life-Writing. New York: St. Martin's Press.

Herrenkohl, Todd I., Seunghye Hong, J. Bart Klika, Roy C. Herrenkohl, and M. Jean Russo. 2013. Developmental Impacts of Child Abuse and Neglect Related to Adult Mental Health, Substance Use, and Physical Health. Journal of Family Violence 28: 191-99. [CrossRef] [PubMed]

Jones, Nev, and Robyn Brown. 2013. The Absence of Psychiatric C/S/X Perspectives in Academic Discourse: Consequences and Implications. Disability Studies Quarterly 33: 1-10. Available online: http:/ /dsq-sds.org/ article/view/3433/3198 (accessed on 23 August 2017).

Kafer, Alison. 2016. Un/Safe Disclosures: Scenes of Disability and Trauma. Journal of Literary and Cultural Disability Studies 10: 1-20. [CrossRef]

Konradi, Amanda. 1993. Teaching about Sexual Assault: Problematic Silences and Solutions. Teaching Sociology 21: 13-25. [CrossRef]

Laub, Dori. 1992. Bearing Witness, or the Vicissitudes of Listening. In Testimony: Crises of Witnessing in Literature, Psychoanalysis, and History. Edited by Shoshana Felman and Dori Laub. London: Routledge.

Lloyd, Roseann. 1991. Writing My Self into Existence. In She Who Is Lost Is Remembered: Healing from Incest through Creativity. Edited by Louise M. Wisechild. Seattle: The Seal Press, pp. 71-87.

Matsakis, Aphrodite. 1996. I Can't Get Over It: A Handbook for Trauma Survivors. Oakland: New Harbinger.

Nicki, Andrea. 2009. Welcoming. Toronto: Inanna Press.

Nicki, Andrea. 2012. Noble Orphan. Toronto: York University.

Nicki, Andrea. 2013. Nightcrawlers. Wordgathering: A Journal of Poetry and Disability Literature Volume 7. Available online: http:/ / www.wordgathering.com/past_issues/issue28/poetry/poetry28.html (accessed on 21 September 2017).

Nicki, Andrea. 2015. Psychological Disability, Mad Activism, and Literary Publishing. Wordgathering: A Journal of Poetry and Disability Literature 9. Available online: http://www.wordgathering.com/past_issues/ issue36/essays / essays36.html (accessed on 21 September 2017). 
Nicki, Andrea. 2016a. Borderline Personality Disorder, Discrimination, and Survivors of Chronic Childhood Trauma. International Journal of Feminist Bioethics 8: 218-45. [CrossRef]

Nicki, Andrea. 2016b. "Pink Balloons." I Am Not a Silent Poet. Available online: https://iamnotasilentpoet. wordpress.com/2016/03/10/pink-balloons-by-NICKI/https:/ /iamnotasilentpoet.wordpress.com/2016/ 03/10/pink-balloons-by-NICKI/ (accessed on 23 August 2017).

Nouwen, Henri J. M. 1972. The Wounded Healer: Ministry in Contemporary Society. New York: Doubleday.

Pecora, Peter J., Jason Williams, Ronald C. Kessler, Eva Hiripi, Kirk O’Brien, John Emerson, Mary A. Herrick, and Dan Torres. 2006. Assessing the educational achievements of adults who were formerly placed in foster child care. Child and Family Social Work 11: 220-31. [CrossRef]

Price, Maraget. 2012. Disability Studies Methodology: Explaining Ourselves to Ourselves. In Practicing Research in Writing Studies: Reflexive and Ethically Responsible Research. Edited by Katrina Powell and Pamela Takayoshi. New York: Hampton, pp. 159-86.

Rak, Julie. 2003. Do Witness: Don't: A Women's Word and Trauma as Pedagogy. Topia 10: 53-71. [CrossRef]

Serota, Michael. 2011. Humanity and Law: In Response to Christine Stark Memoir, Run. University of Pennsylvania Law Review 160: 1-9. Available online: https:/ /scholarship.law.upenn.edu/cgi/viewcontent.cgi?referer= https: / / www.google.ca / \&httpsredir=1\&article=1080\&context=penn_law_review_online (accessed on 11 October 2017).

Spear, Rachel. 2014. Let Me Tell You a Story: on Teaching Trauma Narratives, Writing, and Healing. Pedagogy: Critical Approaches to Teaching Literature, Language, Composition, and Culture 14: 53-79. [CrossRef]

Stark, Christine. 2010. Memoir: Run. University of Pennsylvania Law Review 158: 1575-79. Available online: https:/ /scholarship.law.upenn.edu/penn_law_review/vol158/iss6/ (accessed on 11 October 2017).

Stark, Chistine. 2011. Nickels: A Tale of Dissocation. Ann Arbor: Modern History Press.

Thomas, Sandra P., and Joanne M. Hall. 2008. Life Trajectories of Female Child Abuse Survivors Thriving in Adulthood. Qualitative Health Research 18: 149-66. [CrossRef] [PubMed]

Unrau, Yvonne A. 2011. From Foster Care to College: The Seita Scholars Program at Western Michigan University. Reclaiming Children and Youth 20: 17-20. Available online: https:/ / wmich.edu/sites/default/ files/attachments/u356/2014/2010Unrau.pdf (accessed on 11 October 2017).

Watts, Richard. 2016. For Youth Raised in Care, Break in Tuition Offers Step Up. Times Colonist. July 30. Available online: http:/ / www.timescolonist.com/news/local/for-youth-raised-in-care-break-on-tuition-offers-stepup-1.2313582 (accessed on 11 October 2017).

Wheatwind, Marie-Elise. 1991. First Person, Present Tense: Writing as an Act of Faith. In She Who Is Lost Is Remembered: Healing from Incest through Creativity. Edited by Louise M. Wisechild. Seattle: The Seal Press, pp. 9-19.

Wisechild, Louise M. 1988. The Obsidian Mirror: Healing from Childhood Sexual Abuse. Seattle: Seal Press.

Wolframe, PhebeAnn M. 2013. Reading through Madness: Counter-Psychiatric Epistemologies and the Biopolitics of (In) sanity in Post-World War II Anglo-Atlantic Women's Narratives. Ph.D. dissertation, McMaster University, Hamilton, ON, Canada, December. Available online: https:/ / macsphere.mcmaster.ca/bitstream/ 11375/13900/1/fulltext.pdf (accessed on 2 April 2018).

(C) 2018 by the author. Licensee MDPI, Basel, Switzerland. This article is an open access article distributed under the terms and conditions of the Creative Commons Attribution (CC BY) license (http:// creativecommons.org/licenses/by/4.0/). 